\title{
First Report on Tuberculosis Based on Slaughterhouse Data in Bejaia Province, Algeria: A Retrospective 10-Year Survey
}

\author{
Abdelhanine AYAD ${ }^{1 *}$, Abdelkader BENSID ${ }^{2}$, Amira Chahrazad BENABDELHAK ${ }^{1}$, \\ Fatima AIT-YAHIA ${ }^{3}$, Nadir Boudjlal DERGAL ${ }^{4}$ \\ ${ }^{1}$ Department of Biological Sciences of the Environment, Faculty of Nature and Life Sciences, University of Bejaia, 06000, Algeria. \\ ${ }^{2}$ Department of Agronomy, Faculty of Natural and Life Sciences, Djelfa, 17000, Algeria. \\ ${ }^{3}$ Veterinary Services, Directory of Agricultural Services, 06000, Bejaia, Algeria. \\ ${ }^{4}$ Department of Biotechnology, Faculty of Nature and Life Sciences, University of Oran 1, Oran, 31000, Algeria.
}

\begin{abstract}
Tuberculosis (TB) is a widespread and endemic disease of ruminants in Algeria posing a significant threat to public health. A retrospective abattoir study was conducted in Bejaia province (Algeria) from 2009 to 2018 to estimate the prevalence of tuberculosis in cattle, sheep, and goats using detailed meat inspection procedure. The overall prevalence of tuberculosis was $2.06 \%$ (4092/199 077) in cattle, $0.007 \%(11 / 168796)$ in sheep, and $0.008 \%$ $(11 / 164986)$ in goats. The annual prevalence rate of the disease showed intermittent increase in levels over the ten years period of the study. However, monthly fluctuations of tuberculous lesions in slaughtered cattle were recorded throughout the study period with detection rates ranging from $1.77 \%$ and $2.36 \%$. In addition, the variation in seasonal prevalence in cattle and goats is not significant $(P>0.05)$. Our analysis has revealed the magnitude of TB in the study area and warrants further systematic investigation on the transmission of the disease in Algeria.
\end{abstract}

Keywords: Tuberculosis, Ruminants, Slaughterhouse, Algeria

\section{Cezayir, Bejaia'daki Mezbaha Verilerine Dayanan Tüberküloz Hakkında İlk Rapor: Geriye Dönük 10 Y1llık Bir Araştırma}

ÖZ

Tüberküloz (TB), Cezayir'de halk sağllğı için önemli bir tehdit oluşturan ruminantların yaygın ve endemik bir hastalığıdır. Bejaia'da (Cezayir) sığır eti, koyun ve keçilerde tüberküloz prevalansının ayrıntılı bir et muayene prosedürü kullanılarak tahmin edilmesi için geriye dönük bir mezbaha çalışması yapılmıştır. Tüberküloz prevalansı sı̆ğrlarda \% 2.06 (2.092/199 077), koyunlarda \% 0.007 (11/168 796) ve keçilerde \% 0.008 (11/164 986) idi. Hastalığın yıllık yaygınlık oranı, çalışmanın on yıllık dönemi boyunca aralıklarla artmıştır. Ancak, kesilen sığırlarda aylık tüberküloz lezyonlarındaki dalgalanmalar, çalışma süresi boyunca \% 1.77 ile \% 2.36 arasında değişen tespit oranlarında kaydedilmiştir. Ayrıca sığır ve keçilerde mevsimsel prevalanstaki değişiklik anlamlı değildir (P>0.05). Analizimiz, çalışma alanındaki TB'nin büyüklügünü ortaya çıkarmıştır ve Cezayir'de hastalığın bulaşmasına ilişkin daha fazla sistematik araştırmayı garanti etmektedir.

Anahtar Kelimeler: Tüberküloz, Ruminant, Kesimhane, Cezayir

To cite this article: Ayad A. Bensid A. Benabdelhak. A.C. Ait Yabia F. Dergal N.B. First Report on Tuberculosis Based on Slanghterhouse Data in Bejaia Province, Algeria: A Retrospective 10-Year Survey. Kocatepe Vet J. (2020) 13(2):118-124 


\section{INTRODUCTION}

Tuberculosis (TB) is a worldwide chronic and debilitating zoonotic disease caused by the members of the Mycobacterium tuberculosis complex. It is characterized by progressive development of specific granulomatous lesions (tubercles) in tissues especially in the lungs, lymph nodes, liver, intestines, and kidney where bacteria have localized (Shitaye et al. 2006). Mycobacterium bovis and Mycobacterium tuberculosis are the major causes of TB in a wide range of both domestic and wild warm-blooded animals, and are the sources of TB in humans (O'Reilly and Daborn 1995). Like other mycobacteria, they are very robust in the environment and can survive under extreme environmental conditions (Courtenay et al. 2006; Fine et al. 2011). Indeed, the close interaction between humans and animals reported previously contributes largely to the evolution and transmission of many shared infectious diseases especially the tuberculosis (Thoen et al. 2009). The pathogen can infect humans and animals by ingestion of infected raw milk or colostrum; through aerosol discharges, including sputum, saliva, urine, and manure contact; and through watering and feeding sites (De la Ruta et al. 2006, Silaigwana et al. 2012).

Tuberculosis is a widespread and economically important disease of domestic animals. It negatively affects agricultural activities and causes severe impacts on the productivity of the livestock industry, leading to significant economic losses from livestock deaths, additional processing costs for tuberculous animals, and trade restrictions (De GarineWichatitsky et al. 2013). In addition, infected animals show decrease in milk and in meat production. Tuberculosis is a serious chronic disease and considered as well as a major zoonosis of public health concern global, it is responsible for more deaths than any other microbial disease ever today (Thoen et al. 2016). In the annual reports of World Health Organization (WHO) declared that approximately 10.4 million new Tuberculosis cases were recorded in 2015 and about 1.8 million people died globally (WHO 2016).

In Algeria, the livestock sector plays an important role in the national economy and food security. According to the satirical report of the Ministry of Agriculture and Rural Development, the national herd exceeds 34 million heads including sheep, goats and cattle. Most of the tuberculosis surveys are based on tuberculin skin test, bacteriology and post mortem meat inspection in slaughterhouse that play an important role for surveillance of the disease in many countries as such Algeria. It is urgent to evaluate the magnitude of occurrence of this pathology in animal livestock. Furthermore, slaughterhouse surveillance is the most economically efficient method of detecting infection in herds with a high level of sensitivity and contributes to the eradication of tuberculosis from several developed countries. Therefore, a slaughterhouse can be a potential source of information on the epidemiology of animal affected for this disease (Shittu et al. 2013).

Currently, there is very few available data on animal tuberculosis in slaughterhouses in Algeria especially Bejaia province. For this reason, the objective of the present study was to determine the prevalence of tuberculosis infection based on the records from different local slaughterhouse in Bejaia province from 2009 to 2018.

\section{MATERIALS and METHODS}

\section{Study area}

The study was conducted in Bejaia Province of, $\left(36^{\circ} 43^{\prime} \mathrm{N}, 5^{\circ} 04^{\prime} \mathrm{E}\right)$, which is located in the northeastern of Algeria, and covers a total land mass area of 326.826 -kilometer square $\left(\mathrm{km}^{2}\right)$. The study area receives a mean annual rainfall of about 797.5 $\mathrm{mm}$ with mean annual minimum and maximum temperature range of about 11.3 and $25.5{ }^{\circ} \mathrm{C}$, respectively. It experiences two main seasons: a dry season from June to August, and a rainy season from, September to May, with the greatest falls between December and February. In Bejaia province, cattle, sheep and goats are the most important livestock species $(43,000 ; 115,000 ; 44,000$ of head, respectively).

\section{Routine post-mortem procedures}

A retrospective study was carried out using abattoirs records for cases of TB in animals over a period of ten years from January 2009 to December 2018. The municipals abattoirs were under the supervision of the Directory of Agricultural Services. Routine abattoir inspection of carcasses for detection of visible abnormalities including tuberculous lesions was carried out by the assigned meat inspectors (Veterinarians) based on procedures adopted by Gracey et al. (1999). For this study, diagnosis of tuberculosis in cattle was based on the visual examination of organs such as lungs, liver, kidneys, uterus, spleen, udder, intestines, pericardium, pleura, peritoneum, and incision of tracheobronchial, mediastinal, apical, medial retro-pharyngeal, submaxillary, mesenteric, hepatic, inguinal, and supramammary lymph nodes. Other lymph nodes and organs are incised whenever lesions are detected in one of these tissues. In detail, necropsy procedures were based on gross detection of typical tubercle which is whitish or yellowish in colour, yellowish granulomatous caseated lesions or sometimes 'gritty' calcification in the mentioned tissues. The lymph nodes were sliced into multiple thin sections using knives and examined visually under a bright light source for the presence of TB-like lesions. Diagnosis of tuberculosis in sheep and goats was based only on the visual examination of thoracic and abdominal organs, pericardium, pleura and peritoneum because 
the tuberculosis of progressive generalization is extremely frequent in these species; therefore, tuberculous lesions are visible on the parenchyma of several organs and are similar to those seen in cattle (Gracey et al. 1999).

\section{Determination of prevalence}

The overall prevalence for animal species was calculated from data collected over a ten-year period (2009-2018). Records of monthly and annual returns from abattoirs were scrutinised with regard to the number of animal slaughtered and the corresponding number of infected animals as a result of infection tuberculosis. The annual prevalence of tuberculosis was calculated as the number of cattle with suspect TB lesions divided by the number of animals examined at post-mortem during that particular year and expressed in percentage. The seasonal prevalence was also determined by calculating the total umber of found positive for tuberculous lesions recorded during the rainy season (October, November, December, January, February, Marsh), dry season (April, May, June, July, August, September), divided by the total number of animals examined at postmortem during that particular season and presented in percentage.

\section{Statistical analysis}

All the data were entered, stored and calculated in Microsoft Excel 2007. The retrospective data were analyzed using Statview (Version 4.55). The data were also presented using descriptive statistics in the form of table. Mean were compared using the independent samples $t$-test at 95\% confidence interval. The values were statistically different when the $P$-value was < 0.05 .

\section{RESULTS}

Table 1 shows meat inspection data for the number of slaughtered animal (cattle, sheep and goats) and tuberculosis lesions detection for a ten-years period (January 2009 to December 2018). A total of 181,450 cattle, 163,384 sheep and 145,048 goats were slaughtered and inspected during a 10-year of study period at Bejaia province. There were significant differences $(P \leq 0.05)$ in the mean numbers of animals slaughtered per year during the indicated period. The overall prevalence of tuberculosis detected by post-mortem examination in cattle, sheep and goats slaughtered during the study period was 2.06\% (95\% CI, 0.66-3.38), 0.007\% (95\% CI, 0-0.001) and $0.008 \%(95 \% \mathrm{CI}, 0-0.001)$, respectively. The distribution of tuberculous lesions in slaughtered cattle shows a significant difference when compared to sheep or goats $(P \leq 0.05)$.

A result of annual trends and monthly prevalence of infected animals by tuberculosis during recording period (2009-2018) is illustrated in Figure 1 and 2. In cattle, the rate maximum of tuberculosis was $3.53 \%$ in the year 2018; and a minimum of $0.58 \%$ in the year 2011 , the overall annual prevalence rate of the disease showed intermittent increase in levels over the ten years period of the study. The maximum annual prevalence at tuberculosis cases for sheep and goats were $0.01 \%$ in the year 2014 and 2016, respectively. The monthly prevalence of tuberculosis in slaughtered cattle were recorded throughout the study period with detection rates ranging from $1.77 \%$ and $2.36 \%$. On the other hand, the monthly cumulative prevalence rates of sheep and goats tuberculosis cases recorded varied between $0 \%$ and $0.06 \%$.

The seasonal variation in the prevalence of infected animals due to tuberculosis is summarized in Table 2. The prevalence rates recorded of infected cattle and goats tuberculosis were slightly higher in rainy season than in the dry season. However, this difference was not statically significant. On the other hand, prevalence of tuberculous lesions in sheep recorded during the dry season $(0.01 \%)$ is significantly higher $(P<0.05)$ than in the rainy season $(0.0 \%)$. The overall prevalence of tuberculosis lesions recorded during the rainy season $(0.85 \%)$ is higher compare to dry season and is not significantly different $(P>$ $0.05)$.

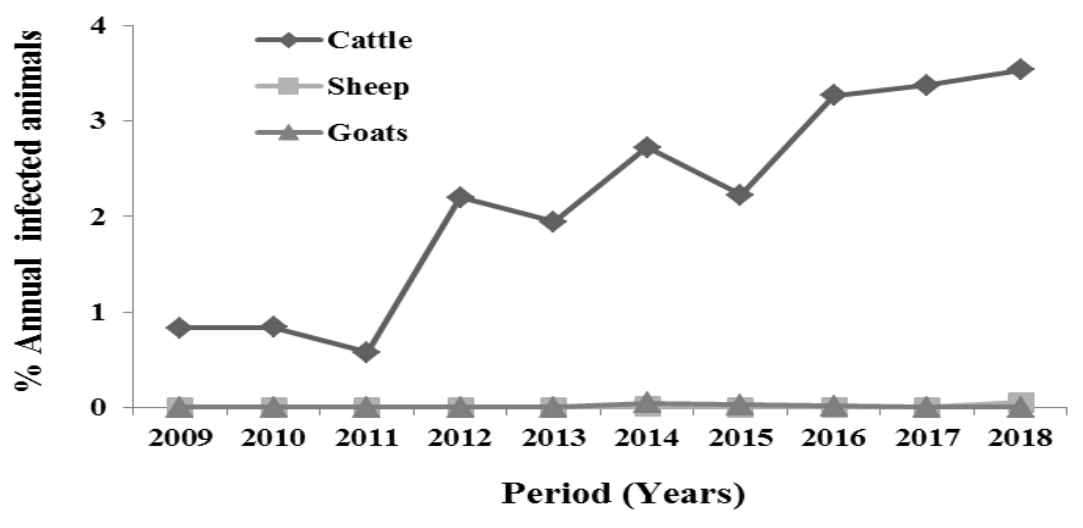

Figure 1. Annual trends of infected animals in slaughtered cattle, sheep and goats as a result of tuberculosis for the period 2009-2018 in Bejaia province 


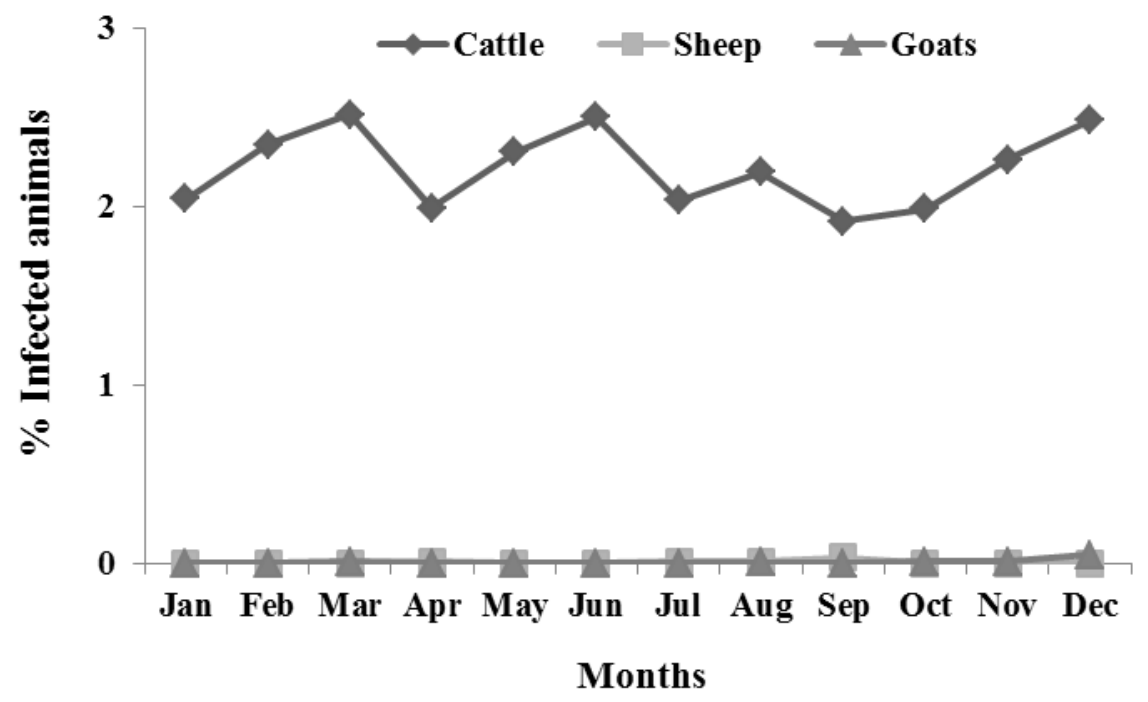

Figure 2. Monthly variations in proportions of infected animals for tuberculosis in slaughterhouse during the year 2009-2018 in Bejaia province

Table 1. Slaughter statistics Tuberculosis rates of infected animal between 2009 and 2018 in Bejaia province

\begin{tabular}{lcccc}
\hline Species slaughtered & Cattle & Sheep & Goats & Animal total \\
\hline Number slanghtered & 199077 & 168796 & 164986 & 532859 \\
Mean $\pm S D$ & $19907.7 \pm 2229$ & $16879.6 \pm 4984.6$ & $16498.6 \pm 5358.6$ & $53285.9 \pm 9677.2$ \\
Min-Max & $17196-23760$ & $12695-28862$ & $9771-24389$ & $40662-67657$ \\
$\begin{array}{l}\text { Number with } \\
\text { tuberculosis lesions }\end{array}$ & 4092 & 11 & 11 & 4114 \\
$\begin{array}{l}\text { Prevalence (\%) } \\
\text { 95\% confidence interval }\end{array}$ & $0.66-3.38$ & $0-0.001$ & $0.008^{\mathrm{b}}$ & 0.77 \\
& & $0.007 \mathrm{~b}$ & $0-0.001$ & $0.13-0.65$ \\
\hline a,b Values with different superscripts in the same raw are significantly different $(P \leq 0.05)$. &
\end{tabular}

Table 2. Seasonal prevalence rates (\%) of tuberculosis in infected animal slaughtered between 2009 and 2018 in Bejaia province

\begin{tabular}{llcc}
\hline Species & Season & $\begin{array}{c}\text { Number } \\
\text { slaughtered }\end{array}$ & $\begin{array}{c}\text { Number of infected } \\
\text { animals by Tuberculum (\%) }\end{array}$ \\
\hline Cattle & Rainy & 87178 & $1979(2.27 \%)$ \\
& Dry & 114033 & $2454(2.15 \%)$ \\
Sheep & Rainy & 72713 & $0(0 \%)^{*}$ \\
& Dry & 106882 & $11(0.01 \%)^{*}$ \\
Goats & Rainy & 75099 & $10(0.013 \%)$ \\
& Dry & 90143 & $1(0.001 \%)$ \\
& Rainy & 234990 & $1989(0.85 \%)$ \\
& Dry & 311058 & $2466(0.79 \%)$ \\
\hline
\end{tabular}

${ }^{*}$ Values with different superscripts in the same species between rain and dry season are significantly different $(P \leq 0.05)$ 


\section{DISCUSSION}

In Africa, epidemiological studies of TB are difficult to perform due to cost and the lack of laboratory techniques, therefore, many epidemiologic and public health aspects of the disease remain mainly unknown. However, the regular post-inspection monitoring of carcasses remains the best option for monitoring animal tuberculosis and can be a valuable source of information on the incidence of animal diseases and conditions, some of which may be zoonotic. The meat inspection data are a potential source of information and have an important role to play in epidemiology and preventive veterinary medicine; however, it is not being fully exploited in Algeria, especially in Bejaia province. In this context, our study aimed at determining the magnitude and distribution of tuberculosis in Bejaia slaughterhouse using a meat inspection procedure from January 2009 to December 2018. To our knowledge, this is one the rare study conducting the prevalence of tuberculosis diagnosed from slaughter in Algeria, especially Bejaia area. However, routine abattoir meat inspection and periodic intra-dermal tuberculin skin testing of cattle from intensive dairy farms have already previously revealed the presence of bTB in Algeria (Sahraoui et al. 2009).

Based on detailed post-mortem inspection, the overall prevalence of tuberculosis in cattle, sheep and goats recorded in the current study $(2.06 \%, 0.007 \%$ and $0.008 \%$, respectively) is widely different compared to several report. The tuberculosis prevalence of bovine slaughtered in the present study $(2.06 \%)$ is lower compared to the previous works (Sahraoui et al. 2011) who reported prevalence of $3.58 \%$ in four abattoirs in the north of Algeria. Likewise, when compared with the data recorded elsewhere in developing countries, the prevalence recorded in this study was lower than $6.1 \%$ prevalence reported in Nigeria by Ahmad et al. (2017), 5.5\% in Ethiopia (Dejene et al. 2016) and $9.7 \%$ in Uganda (Nalapa et al. 2017). However, this rate was higher than the earlier reports based on abattoir post-mortem detection of tuberculosis-like lesions from different regions; $0.78 \%$ (Sa'idu et al. 2017) in Nigeria, $0.48 \%$ (Carvelho et al. 2015) in Brazil, and 0.18\% (Asil et al., 2013) in Sudan. These differences could be explained by many factors including lower cattle density and housing of animals in open areas, which are unlikely to favour the spread of the disease, breed of animals that are slaughtered in the abattoirs, differences in the disease status in the animal populations, and various environmental influences (Regassa et al. 2010). The transmission and development of infection have been found to differ significantly from place to place, and this difference is most probably linked to the climatic conditions affecting the stability of the agent in the environment, type of the production system (intensive, extensive), malnutrition, insufficient aeration system, over stocking and herding of different herd groups (Shitaye et al. 2006).

The tuberculosis prevalence of sheep slaughtered in the present study $(0.007 \%)$ is lower compared to the previous works who reported prevalence over of $0.22 \%$ at two abattoirs in the central region of Algeria (Sahraoui et al. 2012), and 2.85\% in South Darfur State during the period October 2015 to February 2017 (Aljameel et al. 2017). However, this prevalence is higher than the $0.0 \%$ reported by Cadmus et al. (2009) at Bodija municipal abattoir in Oyo state of Nigeria. The rate of caprine tuberculosis is revealed lower $(0.008 \%)$ than the $3.72 \%, 3.5 \%$, and $1.68 \%$ reported by Aljameel et al. (2017) in Sudan, Benti et al. (2013) in Ethiopia and Luboya et al. (2017) in Congo. In one survey conducted in four slaughterhouses in the north of Algeria during the year of 2007, the authors report a prevalence of lesions of caprine tuberculosis of $6.03 \%$ (Sahraoui et al. 2008). The low rate of TB in slaughtered sheep and goats in Bejaia province might be attributed to the housing of sheep and goats separately from cattle at night, and to many factors such as animal source, age, breeding management and hereditary resistance. In addition, separate herding may have contributed to a low contact rate between sheep and goats and the other species of animals (Ghebremariam 2018).

The low percentage of TB in animals in Bejaia province (Algeria) might be indicative of the success of the TB eradication program in domestic animals. Moreover, the majority of Algerian cattle are registered and cattle movement control systems are well established. Also, this may be due to technique conducted by researchers such as microscopic identification of the post mortem lesions of the disease in the slaughtered and tuberculin test technique which are more sensitive (Danbirni et al. 2009). The difference of tuberculosis prevalence might be underestimated in tuberculosis animal slaughtered because of undetected lesions in early infection or because small lesions might be missed as a result of difficulties in carrying out inspection without pressure.

From the results of the epidemiological survey, the tuberculosis cases detected by post-mortem examination in cattle $(2.06 \%)$, was significantly higher than sheep and goats $(0.007 \%$, and $0.008 \%)$ at slaughterhouses of Bejaia province. This could be attributed to many factors such as animal source, age, breeding management and hereditary resistance. These variations could be due to different control practices, particularly the diagnose of the TB to improve livestock production. The prevalence of TB is different in various species due to environmental and management factors (malnutrition, pregnancy and concurrent infection) that may suppress the immune responsiveness of animals. This situation 
could have potential impact on human health directly and threat to human livelihood by compromising food supply, income and social status.

The overall annual prevalence rate of the tuberculosis in cattle showed intermittent increase in levels over the ten (10) years period of the study. The reason for this increasing trend in the prevalence of TB in cattle was not clear. Thus, the increase in the bovine TB detection rate in this study may not have been a real increase of the disease state but is probably due to the intensification of the slaughter/meat inspection procedure. Meat inspection offers an effective means of monitoring the level of TB and depends on the work load, time, and diligence of the veterinary staff conducting the examination (Shitaye et al. 2006). The introduction of modern diagnostic techniques with the intensification of meat inspection and tracing of infected/suspicious cases to the herds of origin would be necessary for effective surveillance of TB. Tuberculous lesions in slaughtered cattle showed monthly fluctuations throughout the study period with detection rates ranging from $1.77 \%$ and $2.36 \%$. Therefore, TB lesions were not influenced by month but it was higher during stressful periods when slaughtering was elevated during religious feasts and sociocultural ceremonies.

In general, the variation in seasonal prevalence in cattle and goats is not significant $(\mathrm{P}>0.05)$, as such there was no association between the occurrence of TB and season in the state. These findings were in concordance with other previous report of AwahNdukum et al. (2010) in Cameron who reported that the detection of TB lesions was not influenced by season but was high during stressful periods such as inter season and peak-season periods. Nwata et al. (2011) showed that variation in seasonal prevalence was not significant; they reported a prevalence of $13.2 \%$ during the rainy season and $12.5 \%$ during the dry season. However, Pollock and Neill (2002) and Ahmed et al. (2013) reported strong association between season and tuberculous lesions but the reason for the difference in the seasonal variations and tuberculous detection observed in their studies was not stated. During the dry season, prevalence of tuberculous lesions in sheep was $0.01 \%$ while the prevalence was lower during the rainy season $(0.0 \%)$; this may be due to the small number of infected sheep, which does not lead to a significant result.

\section{CONCLUSION}

In conclusion, the findings of the present abattoir study have provided a baseline data for monitoring of the ruminant tuberculosis in Bejaia province (Algeria). The results demonstrated that the prevalence of bovine, ovine and caprine tuberculosis recorded was relatively lower than that of some of the previous reports from abattoirs in the same country. However, we suggest that this disease should be investigated further in farms to determine the risks factors on the prevalence in animals such as ages and breeds to develop effective disease control strategies. Also, standardization and intensification of slaughterhouse detailed meat examination and proficiency testing of meat inspections are suggested as essential and costeffective interventions to improve meat inspection service in Algeria, with subsequent protection of consumers' health. Measures to prevent infection transmission among animals and to humans should be the primary objective to be achieved with qualified public health personnel, proper hygiene practices and public education.

\section{ACKNOWLEDGEMENT}

The data collection was made by many veterinary inspectors of communal abattoirs in Bejaia province which are gratefully acknowledged.

Abdelhanine $A Y A D$ designed, carried out the experimental work, analyzed the data and wrote the manuscript. Fatima AIT-YAHLA collected, entered and stored the data in Microsoft Excel. Abdelkader BENSID, Amira Chahrazad. $B E N A B D E L H A K$ and Nadir Boudjlal DERGAL reviewed the manuscript. All authors read and approved the final manuscript.

Conflict of Interest: The authors declare that they have no conflict of interest.

\section{REFERENCES}

Ahmad I, Kudi CA, Abdulkadir AI, Saidu SNA. Occurrence and distribution of bovine TB pathology by age, sex, and breed of cattle slaughtered in Gusau Abattoir, Zamfara State Nigeria. Trop Anim Health Prod. 2017; 49(3): 583589.

Ahmed AM, Ismail SAS,Dessouki AA. Pathological lesions survey and economic loss for male cattle slaughtered at Ismailia abattoir. Int Food Rese J. 2013; 20(2): 857-863.

Aljameel MA, Mohammed GE, Bakhiet AO. Tuberculosis in Sheep and Goats: pathological characteristics based on abattoir Study in South Darfur State, Sudan. Sudan J Sci Technol.2017; 18(2): 107-126.

Asil E, Sanousi S, Gameel A, Beir H, Fathelrahman M, Terab N, Muaz M,Hamid M. Bovine tuberculosis in South Darfur State, Sudan: an abattoir study based on microscopy and molecular detection methods. Trop Anim Health Prod. 2013; 45(2).

Awah-Ndukum J, Kudi AC, Bradley G, Ane-Anyangwe IN, Fon-Tebug S, Tchoumboue J. Prevalence of bovine tuberculosis in abattoirs of the Littoral and Western highland regions of Cameroon: A cause for public health concern. Vet Med Int. 2010.

Benti D, Conraths FJ, Ameni G. Abattoir based study on the epidemiology of caprine tuberculosis in Ethiopia using conventional and molecular tools. Acta Vet Scad. 2013; 55: 15 . 
Cadmus SI, Adesokan, HK, Jenkins AO, Soolingen D. Mycobacterium bovis and Mycobacterium tuberculosis in goats, Nigeria. Emer Infect Dis. 2009; 15(12): 2066-2067.

Carvalho RCT, Furlanetto LV, Maruyama FH, de Araújo CP, Barros SLB, do Nascimento Ramos CA, Dutra V, de Araújo FR, Paschoalin VMF, Nakazato L de Souza Figueiredo EE. Evaluation of the efficiency of nested q-PCR in the detection of Mycobacterium tuberculosis complex directly from tuberculosissuspected lesions in post-mortem macroscopic inspections of bovine carcasses slaughtered in the state of Mato Grosso, Brazil. Meat sci. 2015; 106: 11-15.

Courtenay O, Reilly LA, Sweeney FP, Hibberd V, Bryan S, U1-Hassan A, Newman C, Macdonald DW, Delahay RJ., Wilson GJ, Wellington EMH. Is Mycobac-terium bovis in the environment important for the persistence of bovine tuberculosis? Biol Lett. 2006; 2: 460-462.

Danbirni S, Sackey AKB, Kudi AC, Okaiyeto SO, Pewan SB. A comparison of One- Step Anigen ${ }^{\circledR}$ Rapid Bovine TuberculosisAntibodies Test Sensitivity to Postmortem Gross Lesions in Diagnosing Bovine Tuberculosis in a Dairy Herd in Kaduna State. Res J Dairy Sci. 2009; 3(2-4): 3234.

De Garine-Wichatitsky M, Caron A, Kock R, Tschopp R, Munyeme M, Hofmeyr M, Michel A. A review of bovine tuberculosis at the wildlife-livestock-human interface in sub-Saharan Africa. Epidemiol Infect 2013; 141(7): 1342-1356.

De la Rua-Domenech R. Human Mycobacterium bovis infection in the United Kingdom: Incidence, risks, control measures and review of the zoonotic aspects of bovine tuberculosis. Tuberculosis 2006; 86(2): 77-109.

Dejene SW, Heitkönig IMA, Prins HHT, Lemma FA, Mekonnen DA, Alemu ZE, Kelkay TZ, de Boer WF. Risk Factors for Bovine Tuberculosis (bTB) in Cattle in Ethiopia. PLoS One. 2016; 11(7)

Fine AE, Bolin CA, Gardiner JC, Kaneene JB. A study of the persistence of Mycobacterium bovis in the environment under natural weather conditions in Michigan, USA. Vet Med Int. 2011.

Ghebremariam MK, Michel AL, Vernooij JCM, Nielen M, Rutten VPMG. Prevalence of bovine tuberculosis in cattle, goats, and camels of traditional livestock raising communities in Eritrea. BMC Vet Res. 2018; 14(1): 73.

Gracey JF, Collins DS, Huey RJ. Meat hygiene (1999). 10 $0^{\text {th }}$ ed. London: Elsevier Healthy Sciences. (543-553). Chapter 17: Infectious diseases.

Luboya LW, Malangu M, Kaleka M, Ngulu N, Nkokele B, Maryabo K, Pourrut X, Vincent T, Gonzalez JP. An assessment of caprine tuberculosis prevalence in Lubumbashi slaughterhouse, Democratic Republic of Congo. Trop Anim Health Prod. 2017; 49(4): 875-878

Nalapa DP, Muwonge A, Kankya C, Olea-Popelka F. Prevalence of tuberculous lesion in cattle slaughtered in Mubende district, Uganda. BMC Vet Res. 2017; 13(1): 73.

Nwata JA, Umeononigwe CN, Abonyi GE and Onunkwo JI Retrospective study of bovine and human tuberculosis in abattoirs and hospitals in Enugu State, Southeast Nigeria. J Public Health Epidemiol. 2011; 3(7): 329-336.

O'Reilly LM, Daborn CJ. The epidemiology ofMycobac- terium bovis infections in animals and man: a review. Tuber Lung Dis. 1995; 76(1): 1-46.

Pollock JM, Neill SD. Mycobacterium bovis infection and tuberculosis in cattle. Vet J. 2002; 163: 115-27.
Regassa A, Tassew A, Amenu K, Megersa B, Abunna F, Mekibib B, Macrotty T, Ameni G. A cross-sectional study on bovine tuberculosis in Hawassa town and its surroundings, Southern Ethiopia. Trop Anim Health Prod. 2010; 42(5): 915-920.

Sa'idu AS, Mohammed S, Ashafa M, Gashua MM, Mahre MB, Maigado AI. Retrospective study of bovine tuberculosis in Gombe Township Abattoir, Northeastern Nigeria. Int J Vet Sci Med. 2017; 5(1): 65-69.

Sahraoui N, Hasniou A, Chettab H, Ben Khada G, Tazerart F, Chadi H, Zinsstag J, Guetarni D. Diagnostic de la tuberculose ovine par examen anatomopathologique en Algérie. Journal Recherche Scientifique de l'Université de Lomé. 2012; 14(2): 143-147.

Sahraoui N, Müller B, Guetarni D, Boulahbal F, Yala D, Ouzrout R, Berg S, Smith NH, Zinsstag J. Molecular characterization of Mycobacterium bovis strains isolated from cattle slaughtered at two abattoirs in Algeria. BMC Vet Res. 2009; 5(1): 4.

Sahraoui N, Muller B, Mamache B, Yala D, Boulahbal F, Zinsstag J, Guetarni D. Tuberculosis in cattle and goats in north of Algeria. Vet Res. 2011; 4(4): 100-103.

Sahraoui N, Muller B, Yala D, Ouzrout R, Zinsstag J, Boulahbal F, Guetarni D. Investigation about the bovine tuberculosis in two Algerian slaughterhouses. Afric J Agricult Res 2008; 3(11): 775-778.

Shitaye JE, Getahun B, Alemayehu T, Skoric M, Treml F, Fictum P, Vrbas V, Pavlik I. A prevalence study of bovine tuberculosis by using abattoir meat inspection and tuberculin skin testing data, histopathological and IS6110 PCR examination of tissues with tuberculous lesions in cattle in Ethiopia. Vet Med. 2006; 51: 512-522.

Shittu A, Clifton-Hadley RS, Ely ER, Upton PU, Downs SH. Factors associated with bovine tuberculosis confirmation rates in suspect lesions found in cattle at routine slaughter in Great Britain, 2003-2008. Prev Vet Med.2013; 110(34): 395-404.

Silaigwana B, Green E, Ndip R. Molecular Detection and Drug Resistance of Mycobacterium tuberculosis Complex from Cattle at a Dairy Farm in the Nkonkobe Region of South Africa: A pilot study. Int J Environ Res Public Health. 2012; 9: 2045-2056.

Thoen CO, LoBue P, Enarson DA, Kaneene JB, de Kantor IN. Tuberculosis: a re-emerging disease of animals and humans. Vet Ital, 2009; 45: 135-181.

Thoen, C., LoBue, P. and de Kantor, I., 2006. The importance of Mycobacterium bovis as zoonoses, Veterinary Microbiology, 112, 339-345.

World Health Organization. Global Tuberculosis Report; 2016 (Available http://apps.who.int/iris/bitstream/10665/250441/1/97 89241565394-eng.pdf?ua $=1$ (accessed October 23, 2019). 